\title{
PEMBELAJARAN KOOPERATIF TIPE THINK PAIR SHARE (TPS) DILENGKAPI MEDIA REALIA UNTUK MENINGKATKAN AKTIVITAS DAN HASIL BELAJAR BIOLOGI
}

\author{
Eka Setiyarini \\ Agus Sujarwanta \\ Pendidikan Biologi FKIP Universitas Muhammadiyah Metro \\ E-mail: echa_037@yahoo.com
}

\begin{abstract}
Based on result of observed in VII grades of SMP Negeri 2 Tegineneng, in learning process students participant is low so learning process is not active. That's conditions make the result of biological studies was low. The purpose of this research is to improve activity studies and the result of biological studies using the Cooperative learning of think pair share method with a realia media in VII grades of SMP Negeri 2 Tegineneng, amounting to 30 students. This study is a Classroom Action Research (PTK) with two cycle each consisting of three sessions. Activity of studies has incrased from cycle I to cycle II. $16.67 \%$ for attendtioning of teacher, 14,99\% for thingking the work papper, 18,32\% for pairing on discuss, and 19,99\% for sharing the result of discuss on class. Data on students' cycle I into cycle II incrased of $13,34 \%$ was passing the exam. From the result of these studies suggest that the teacher to apply these method in teaching science, especially biology.
\end{abstract}

Kata kunci: Think pair share, media realia, aktivitas dan hasil belajar biologi

Mewujudkan sistem dan misalnya melalui penerapan suatu pelaksanaan pendidikan yang baik dan media pembelajaran. Media bermutu, telah banyak diusahakan oleh pembelajaran merupakan salah satu alat pemerintah dengan diterapkannya bantu dalam pencapaian tujuan Undang-undang system Pendidikan pembelajaran melalui media Nasional, peningkatan mutu tenaga pembelajaran materi pelajaran yang pendidik dan tenaga kependidikan, disampaikan oleh guru akan mudah pembenahan kurikulum, perbaikan diterima dan dipahami oleh siswa. sarana dan prasarana pendidikan. Tetapi Selain itu juga metode pembelajaran ini belum menjamin pendidikan untuk yang variatif dan disesuaikan dengan mempunyai mutu yang baik, karena materi juga berpengaruh penting dalam pada kenyataan yang ada, hasil belajar biologi pada umumnya masih rendah bila dibandingkan hasil belajar siswa pada mata pelajaran lainnya.

Hal ini menunjukkan bahwa dalam suatu proses pembelajaran diperlukan adanya perlakuan pembelajaran, pembelajaran.

Berdasarkan hasil prasurvei yang dilaksanakan di SMP Negeri 2 Tegineneng kelas VIIc semester ganjil tahun pelajaran 2011/2012 diperoleh data hasil belajar biologi siswa sebagai berikut: 
Tabel 1: Hasil Belajar Siswa Kelas VII.c Semester Ganjil SMP Negeri 2 Tegineneng Tahun Pelajaran 2011/2012

\begin{tabular}{|c|c|c|c|c|}
\hline No. & Nilai & Ketuntasan & Jumlah siswa & Presentase \\
\hline 1. & $\geq 65$ & Tuntas & 12 & $40 \%$ \\
2. & $<65$ & Belum tuntas & 18 & $60 \%$ \\
\hline \multicolumn{2}{|r|}{ Jumlah Total } & & 30 & $100 \%$ \\
\hline
\end{tabular}

Sumber: Daftar nilai ulangan harian siswa kelas VII.c semester ganjil SMP Negeri

2 Tegineneng tahun pelajaran 2011/2012(KKM=65)

Dari data yang diperoleh tersebut terdapat $41 \%$ siswa yang telah mencapai kriteria ketuntaasan belajar dan 59\% siswa yang belum mencapai kriteria ketuntasan belajar dari jumlah siswa kelas tersebut sebanyak 30 siswa. Dari hasil perolehan nilai tersebut dapat mengindikasikan adanya permasalahan dalam proses belajar mengajar di kelas VII.c terkait pelajaran biologi.

Melihat dari permasalahan tersebut maka peneliti mencoba mencari solusi yang tepat untuk meminimalisir permasalahan yang ada yaitu dengan cara menggunakan metode belajar dan melengkapinya dengan media yang sesuai dengan materi yang diajarkan. Metode belajar yang dipilih oleh peneliti adalah metode cooperative learning tipe TPS yang kemudian dikombinasikan dengan media Realia.

Cooperative learning atau pembelajaran kooperatif adalah salah satu pembelajaran yang berorientasi konstruktivisme. Cooperative learning merupakan strategi pembelajaran yang memberdayakan siswa melalui kelompok-kelompok kecil. Seperti yang telah dikemukakan oleh Slavin (1995) bahwa Cooperative Learning bertujuan mengembangkan dan meningkatkan hasil belajar akademik, menerima adanya keragaman dan pengembangan keterampilan.

Menurut Trianto (2007:61) “ThinkPair-Share adalah jenis pembelajaran kooperatif yang dirancang untuk mempengaruhi pola interaksi siswa.
Model think-pair-share (TPS) ini dikembangkan oleh Frank Lyman yang menyatakan bahwa think-pair-share merupakan suatu cara yang efektif untuk membuat variasi suasana pola diskusi kelas.

Keunggulan metode pembelajaran kooperatif tipe TPS dibandingkan dengan metode kooperatif lainnya adalah lebih ditekankan pada pembentukan tanggung jawab baik individu maupun kelompok. Selanjutnya dengan media belajar realia siswa dapat lebih menumbuhkan minat belajarnya dengan media yang lebih menarik dalam proses belajar karena dapat melihat secara langsung objek yang dijadikan bahan belajar.

Menurut Rahadi (2004:20) "media Realia adalah benda asli, benda nyata yang digunakan sebagai bahan atau sumber belajar”. Media realia adalah benda nyata. Benda tersebut tidak harus dihadirkan ke ruang kelas tetapi siswa dapat melihat secara langsung ke objek.

Selain itu Aktivitas belajar merupakan kegiatan yang sangat penting dalam pembelajaran. Seperti yang diungkapkan Sardiman (2001: 95)

Dalam belajar sangat diperlukan adanya aktivitas, tanpa aktivitas belajar tidak mungkin berlansung dengan baik. Aktivitas dalam proses belajar merupakan rangkaian kegiatan yang meliputi keaktifan siswa dalam mengikuti pelajaran, bertanya tentang hal yang 
belum jelas, mencatat, mendengar, berfikir, membaca dan segala kegiatan yang dilakukan untuk menunjang aktivitas belajar.

Hamalik (2007:36) menyatakan bahwa "hasil belajar bukan suatu penguasaan hasil latihan, melainkan perubahan kelakuan”. Hasil belajar merupakan nilai yang diperoleh siswa setelah adanya proses pembelajaran tertentu. Hasil belajar juga sering diartikan sebagai perolehan belajar, yang berarti segala sesuatu yang diperoleh siswa dalam proses belajar, berupa aspek kognitif, psikomotorik, dan afektif.

Dari pendapat di atas dapat diketahui bahwa hasil belajar merupakan hal yang sangat penting, karena digunakan untuk mengetahui sejauh mana siswa memahami dan menguasai materi yang telah dipelajarinya. Sedangkan bagi guru, hasil belajar siswa dapat digunakan sebagai bahan evaluasi dalam rangka untuk mengukur keefektifan sistem pembelajaran serta untuk memperbaiki proses pembelajaran dan penguasaan tujuan tertentu dalam kelas.

\section{METODE}

Penelitian ini menggunakan pendekatan Penelitian Tindakan Kelas (PTK), dilaksanakan pada semester genap di SMP Negeri 2 Tegineneng Tahun Pelajaran 2011/2012, yang menjadi subjek penelitian adalah siswa kelas VIIc yang berjumlah 22 siswa dengan tingkat kemampuan yang beragam. Sedangkan objek penelitian metode Think-Pair-Share disertai media Realia dalam meningkatkan aktivitas dan hasil belajar siswa pada materi pokok ciri dan klasifikasi makhluk hidup. Pelaksanaan penelitian ini dimulai pada tanggal 10 april 2012 dan berakhir pada tanggal 21 april 2012. Penelitian dilaksanakan 2 siklus, masing-masing siklus terdiri dari 3 kali pertemuan dengan alokasi waktu 5x40 menit

Dalam penelitian, peneliti melakukan tahap-tahap penelitian dengan kegiatan-kegiatan pada tahap perencanaan yaitu bersama guru mengkaji materi yang akan dilakukan dalam proses pembelajaran selama penelitian, setelah itu mempersiapkan segala perangkat pembelajaran yang akan digunakan selama penelitian seperti silabus, rencana pelaksanaan pembelajaran, membuat lembar observasi siswa yang digunakan untuk melihat aktivitas belajar siswa saat proses pembelajaran berlangsung, membuat LKS, dan soal evaluasi pembelajaran. Pelaksanaan tindakan dilakukan oleh guru dan peneliti dengan melaksanakan pembelajaran dengan penerapan metode TPS disertai media Realia.

Observasi dilakukan berbarengan dengan pelaksanaan tindakan, dan dilakukan oleh peneliti serta dua orang anggota tim observer lain. Pada setiap akhir siklus diadakan tes evaluasi yang digunakan sebagai tolak ukur akan kemampuan untuk memahami materi oleh siswa yang diberikan oleh peneliti dan guru. Pada tahap terakhir adalah refleksi dilakukan pada setiap akhir siklus dalam mengkaji pembelajaran yang dilakukan.

\section{HASIL PENELITIAN}

Berdasarkan hasil observasi pada penelitian yang telah dilakukan, keterampilan proses sains siswa mengalami peningkatan dari siklus I ke siklus II. Hal tersebut dapat dilihat pada Gambar 1.

Dari Gambar 1, dapat dilihat bahwa hasil aktivitas belajar siswa yang terjadi selama dua siklus ini mengalami peningkatan dari setiap siklusnya. Seperti yang telah dideskripsikan bahwa 
data aktivitas belajar siswa yang terjadi pada siklus I memang belum tercapai target dari semua aktivitas yang diamati, karena berdasarkan hasilnya aktivitas yang tercapai pada siklus I hanya satu aktivitas yang dikatakan tercapai yaitu memikirkan soal dalam LKS dengan indikator mencari jawaban dengan membaca literatur yang sesuai dengan materi telah mencapai target $80 \%$ pada akhir siklus I ini.

Selanjutnya yang terjadi pada siklus II bahwa hasil pengamatan yang didapat terkait aktivitas belajar siswa di kelas selama siklus II berlansung bahwa seluruh aktivitas yang diamati pada siklus ini telah mencapai target yang ditentukan pada masing-masing aktivitas yang diamati tersebut. Dari hasil tersebut pula diketahui bahwa aktivitas belajar siswa mengalami peningkatan dari siklus I ke siklus II.

Berdasarkan hasil tes yang dilakukan, hasil belajar siswa pada siklus I dan siklus II mengalami peningkatan. Peningkatan hasil belajar ini juga ditunjukan oleh peningkatan jumlah siswa yang telah tuntas belajar. Peningkatan hasil belajar siswa tersebut dapat dilihat pada Gambar 2.

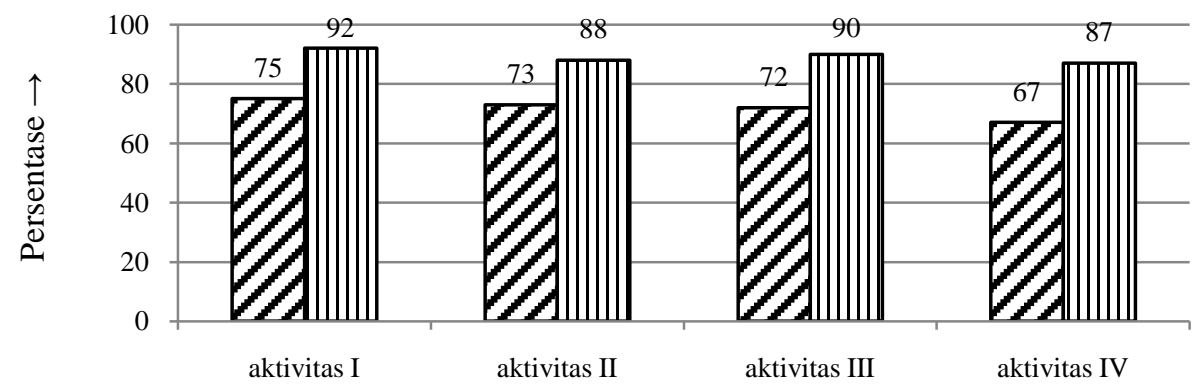

Gambar 1. Diagram Batang Peningkatan Aktivitas Belajar Siswa

Keterangan: $\square=$ Siklus I

Aktivitas I = Memperhatikan penjelasan guru

Aktivitas II = Memikirkan jawaban dalam Lembar Kerja Siswa

Aktivitas III = Berdiskusi dalam pasangan

Aktivitas IV = Berbagi hasil diskusi keseluruh kelas.

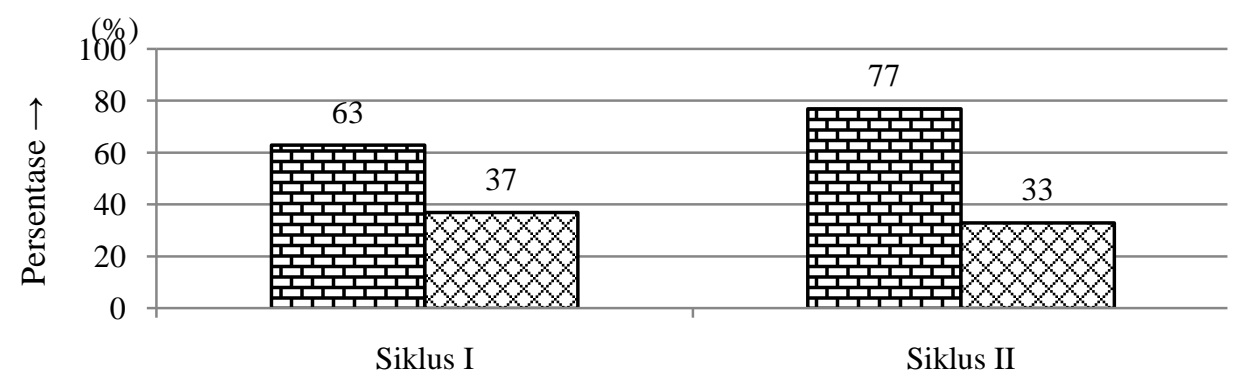

Gambar 2. Diagram Batang Peningkatan Hasil Belajar Siswa dari Siklus I sampai Siklus II

Keterangan: 譼 = Tuntas

济 Tidak Tuntas 
Berdasarkan Gambar 2, dapat dilihat bahwa tingkat ketuntasan hasil belajar siklus I sebesar 63,33\%, sedangkan pada siklus II tingkat ketuntasan hasil belajar 76,67\% jadi tingkat ketuntasan hasil belajar siswa dari siklus I dan siklus II terjadi peningkatan 13,34\%, maka target yang diinginkan telah tercapai untuk ketuntasan belajar siswa pada akhir siklus telah melebihi target yang ditentukan yaitu $70 \%$.

\section{PEMBAHASAN}

Berdasarkan hasil penelitian yang telah diuraikan di atas, maka diperoleh gambaran tentang bagaimana pembelajaran dengan menggunakan metode TPS yang disertai media realia untuk meningkatkan aktivitas dan hasil belajar siswa pada materi pokok Ciri-ciri dan klasifikasi makhluk hidup. Berikut akan diuraikan mengenai bagaimana metode ini berpengaruh dalam setiap aktivitas yang diamati pada saat pembelajaran baik aktivitas maupun hasil belajar biologi siswa:

\section{Aktivitas Belajar Siswa}

Dari hasil penelitian data persentase rata-rata aktivitas belajar siswa dalam pembelajaran melalui metode pembelajaran kooperatif tipe TPS disertai media realia mengalami peningkatan pada setiap siklusnya.

a) Memperhatikan Guru Menjelaskan

Pada siklus I dan II untuk indikator memperhatikan guru menjelaskan diperoleh hasil rata-rata pada siklus I yaitu $75 \%$ dan $91,67 \%$ pada siklus II. Untuk indikator memperhatikan guru menjelaskan, target yang diinginkan telah tercapai karena presentasenya telah mencapai 90\% diakhir siklus. Hal tersebut terwujud karena adanya rasa hormat siswa dan rasa menghargai kepada guru yang sedang mengajar dari awal siklus I hingga akhir siklus II, dan tidak hanya itu saja bahwa meningkatnya aktivitas siswa khususnya pada aspek memperhatikan guru menjelaskan adalah dikarenakan siswa mulai menyadari betapa pentingnya memperhatikan guru menjelaskan materi pelajaran. Selain itu penggunaan media yang secara lansung dapat dilihat yaitu media realia cukup membangkitkan aktivitas belajar siswa dalam memperhatikan penjelasan guru yang dirasa lebih menarik pada proses pembelajaran dengan menggunakan metode TPS disertai media realia. Jadi dari uraian diatas bahwa siswa telah melakukan aktivitas belajar, hal ini sesuai dengan apa yang kemukakan oleh Paul (dalam Hamalik 2007: 172) bahwa jenis-jenis aktivitas itu terbagi menjadi: kegiatan visual, lisan (Oral), mendengarkan, memperhatikan, menggambar, memetrik, kegiatan mental dan emosional.

b) Memikirkan Soal dalam Lembar

Kerja Siswa (LKS)

Pada siklus I dan II untuk indikator memikirkan soal dalam lembar kerja siswa diperoleh hasil rata-rata pada siklus I yaitu 73,34\% dan pada siklus II yaitu 88,33\%. Untuk indikator memikirkan soal dalam lembar kerja siswa (LKS) yang diinginkan telah tercapai yaitu ratarata aktivitas siswa telah mencapai 80\% pada akhir siklus, hal tersebut disebabkan karena siswa senantiasa mempergunakan waktu yang telah diberikan guru untuk berpikir mengenai permasalahanpermasalahan tersebut sesuai dengan yang diungkapakan Wahyudi (2007:12) bahwa keunggulan 
pembelajaran tipe TPS ialah untuk membentuk tanggung jawab individu dan kelompok. Setiap siswa akan lebih berpikir dan mempunyai pendapat sendiri dalam menyelesaikan tugas individu yang berkaitan dengan tugas kelompok.

c) Diskusi dalam Pasangan

Pada siklus I dan II untuk indikator diskusi dalam pasangan diperoleh, pada siklus I yaitu $71,67 \%$ dan pada siklus II yaitu 89,99\%. Untuk indikator diskusi dalam pasangan target yang diinginkan telah tercapai yaitu rata-rata aktivitas siswa telah mencapai target yaitu $80 \%$ pada akhir siklus, hal tersebut disebabkan karena sebagian besar siswa mengakui bahwa pemikiran sendiri tidak lebih baik dibandingkan dengan pemikiran secara bersama. Maka dengan dasar inilah siswa menyatukan pendapatnya untuk memperoleh jawaban yang terbaik. Hal ini sesuai dengan yang dikemukakan oleh Wena (2009:192) bahwa salah satu unsur dasar dalam pembelajaran kooperatif adalah setiap anggota harus belajar menyumbangkan pikiran demi keberhasilan kelompok, untuk mencapai tujuan kelompok (hasil belajar kelompok).

d) Berbagi Hasil Diskusi dengan Keseluruhan Kelas

Pada siklus I dan II untuk indikator berdiskusi berbagi hasil diskusi keseluruh kelas diperoleh pada siklus I yaitu $66,67 \%$ dan $86,66 \%$ pada siklus II. Untuk indikator berbagi hasil diskusi dengan keseluruhan kelas diperoleh, target yang diinginkan telah tercapai yaitu rata-rata aktivitas siswa telah mencapai target yang diinginkan peneliti yaitu mencapai $80 \%$ pada akhir siklus. Hal tersebut disebabkan karena sebagaian besar siswa menyadari bahwa ketika ilmu pengetahuan itu disampaikan kepada orang lain maka ilmu itu tidak akan berkurang akan tetapi akan menambah kefahaman kepada orang yang menyampaikannya, dan dengan berbagi maka siswa akan mengetahui kekurangan-kekurangan atau kesalahan karena ketika salah seorang siswa mempresentasikan maka siswa yang lain diperkenankan untuk menanggapinya. Hal ini sesuai dengan yang telah dikemukakan oleh Assyafi'i (2009: 43) bahwa salah satu kelebihan metode TPS adalah siswa memperoleh kesempatan untuk mempresentasikan hasil diskusinya dengan seluruh siswa sehingga ide yang ada menyebar.

Dari pembahasan tersebut telah dijabarkan tentang bagaimana fase-fase pada metode TPS ini dapat mempengaruhi aktivitas belajar siswa di kelas. Selain dari penggunaan metode TPS, pembelajaran pada penelitian ini juga didukung dengan penggunaan media realia yang merupakan media asli yang memiliki keunggulan bahwa dengan menggunakan media realia ini dapat menarik semangat belajar siswa pada saat memperhatikan penjelasan guru, kemudian siswa juga mendapatkan pengalaman secara lansung terkait dengan objek yang menjadi bahan pembelajarn, dan selain itu bahwa media relia ini juga dapat memberikan informasi yang lebih banyak didapatkan siswa dengan melihat lansung objeknya serta dapat meninggalkan kesan yang akan lebih lama untuk dapat diingat oleh siswa. Sehingga dari pembahasan tersebut dapat disimpulkan bahwa model pembelajaran kooperatif tipe TPS disertai media realia dapat meningkatkan aktivitas belajar siswa. 


\section{Hasil Belajar Siswa}

Berdasarkan hasil tes yang dilakukan, hasil belajar siswa pada siklus I ke siklus II mengalami peningkatan terkait siswa yang tuntas belajar. Berdasarkan hasil analisis data yang telah dilakukan bahwa hasil belajar pada siklus I memang belum mencapai target yang diinginkan, namun pada akhir siklus II telah tercapai target dengan presentase siswa yang tuntas dalam pembelakaran sebanyak 76,67\% dan sisanya sebanyak 23,33\% belum tuntas. Dari hasil tersebut telah mencapai target yang ditentukan sebanyak 70\%.

Meningkatnya hasil belajar siswa dari siklus I ke siklus II disebabkan karena prosedur yang ada dalam pembelajaran kooperatif tipe TPS, dimana ketika seorang siswa diberikan waktu yang banyak untuk melakukan aktivitas berpikir maka secara langsung siswa memperoleh pengetahuan yang mendalam sehingga siswa mampu dalam menyelesaikan setiap permasalahan yang hadapkan kepadanya, dan ditambah ketika siswa mengalami kesulitan dalam mencerna atau memahami materi maka ia mempunyai kesempatan untuk menanyakan kepada temannya, dan temannya akan merespon dan memberikan bantuan kepadanya karena setiap siswa mempunyai pemahaman bahwa setiap siswa harus bertanggung jawab atas keberhasilan temannya yang lain atau dengan kata lain jiwa saling membantu terdapat pada diri setiap siswa. Sehingga pada saat siswa mengerjakan tes yang diberikan guru siswa dapat mengerjakan dengan baik dan benar. Hal ini sesuai dengan apa yang dikemukakan oleh Sidharta (2004) bahwa "prosedur yang digunakan dalam TPS dapat memberikan siswa lebih banyak waktu berpikir, untuk saling merespon dan membantu". Selain itu penggunaan media belajar dalam hal ini media realia sebagai penunjang minat belajar siswa dalam memperhatikan penjelasan guru mengenai materi yang disajikan dengan menggunakan media yang sesuai dapat memberikan pengalaman lansung dan nyata terkait dengan apa yang menyangkut dengan meteri yang ada. Hal ini sesuai dengan yag diunkapkan Rahadi (2004:20) bahwa kelebihan dari penggunaan media realia ini akan memberikan pengalaman yang nyata kepada siswa dengan melihat lansung apa yang menjadi objek belajarnya.

Dari pembahasan diatas telah dipaparkan bagaimana metode belajar TPS serta media realia ini berpengaruh dalam kegiatan belajar siswa baik aktivitas maupun hasil belajarnya. Sehingga dapat disimpulkan bahwa model pembelajaran kooperatif tipe TPS disertai media realia dapat meningkatkan hasil belajar siswa.

\section{KESIMPULAN DAN SARAN}

\section{Kesimpulan}

Berdasarkan analisis data
penelitian tindakan kelas yang
dilakukan, maka dapat disimpulkan
sebagai berikut:

1. Penerapan metode cooperative learning tipe Think Pair Share yang disertai media Realia dapat meningkatkan aktivitas belajar siswa kelas VIIc semester genap SMP Negeri 2 Tegineneng Tahun Pelajaran 2011/2012 pada materi pokok Ciri dan Klasifikasi Makhluk Hidup. Peningkatan yang terjadi sebagai berikut: memperhatikan guru menjelaskan sebesar 16,67\%, memikirkan soal dalam LKS sebesar 14,99\%, kemudian diskusi dalam pasangan mengalami peningkatan sebesar 18,32\% dan kegiatan berbagi hasil diskusi keseluruh kelas mengalami peningkatan sebesar 19,99\%. 
2. Penerapan metode cooperative learning tipe Think Pair Share yang disertai media Realia dapat meningkatkan hasil belajar siswa kelas VIIc semester genap SMP Negeri 2 Tegineneng Tahun Pelajaran 2011/2012 pada materi pokok Ciri dan Klasifikasi Makhluk Hidup. Peningkatan yang terjadi pada hasil belajar siklus I ke siklus II adalah sebesar 13,34\%.

\section{Saran}

Berdasarkan kesimpulan penelitian tindakan kelas ini, maka peneliti menyarankan:

1. Bagi guru. Untuk meningkatkan aktivitas belajar siswa dan hasil belajar siswa pada materi Ciri dan Klasifikasi Makhluk Hidup, maka guru dapat menerapkan TPS yang disertai media Realia.

2. Bagi siswa. Siswa bersungguhsungguh dalam pelaksanaan pembelajaran serta melakukan setiap aktivitas dengan baik agar hasil yang diperolehpun baik

\section{DAFTAR RUJUKAN}

Assyafi'i. 2009. Kelebihan-KekuranganTPS. (Online). http://Ariffadholi.Blogspot.com. diakses 12 Oktober 2009.

Hamalik, Oemar. 2007. Proses Belajar Mengajar. Jakarta: Bumi Aksara.

Rahadi, Aristo. 2004. Media pembelajaran. Jakarta: DepdiknasTenaga Kependidikan

Sardiman. 2001. Interaksi dan Motivasi Belajar Mengajar. Jakarta: Raja Grafindo Persada.

Sidharta, Arief. 2004. Pembelajaran Kooperatif. Bandung: Depdiknas P3G IPA
Slavin, Robert E. 1995. Cooperative Learning: Theory, Reaserch, And Practice. Massachussets: A Simon \& Schuter Company.

Trianto. 2007

Model-Model

Pembelajaran Inovatif Berorientasi Kontruktivistik. Jakarta: Prestasi Pustaka.

Wahyudi, Indra. 2007. Upaya Meningkatkan Ketuntasan Belajar Fisika melalui Pembelajaran Cooperative Learning Model Think Pair Share pada Siswa Kelas X SMA Muhammadiyah Trimurjo Semester Ganjil Tahun Pelajaran 2006/2007. Skripsi. Metro : UM Metro dan Pemerintah Kota Metro.

Wena, Made. 2009. Strategi Pembelajaran Inovatif Kontemporer. Jakarta: Bumi Aksara.

Universitas Muhammadiyah Metro. 2008. Pedoman Penulisan Karya Ilmiah. Metro: UM Metro. 